Chirurgia (2017) 112: 278-288

No. 3, May - June

Copyright@ Celsius

http://dx.doi.org/10.21614/chirurgia.112.3.278

\title{
Comparative Analysis between Simultaneous Resection and Staged Resection for Synchronous Colorectal Liver Metastases - A Single Center Experience on 300 Consecutive Patients
}

\author{
Sorin Alexandrescu' ${ }^{1}$, Andrei Diaconescu', Zenaida Ionel', Cristian Zlate', Răzvan Grigorie', Doina Hrehoreț', \\ Vladislav Brașoveanu', Simona Dima', Florin Botea', Mihnea Ionescu', Dana Tomescu², Gabriela Droc'2, \\ Ruxandra Fota ${ }^{2}$, Adina Croitoru ${ }^{3}$, Iulia Gramaticu ${ }^{3}$, Florina Buica ${ }^{3}$, Razvan lacob ${ }^{4}$, Cristian Gheorghe ${ }^{4}$, \\ Vlad Herlea ${ }^{5}$, Mugur Grasu' ${ }^{6}$, Radu Dumitru ${ }^{6}$, Mirela Boroș ${ }^{6}$, Irinel Popescu' \\ "Dan Setlacec" Center of General Surgery and Liver Transplantation, Fundeni Clinical Institute, Bucharest, Romania \\ ${ }^{2}$ Center of Anesthesiology and Intensive Care, Fundeni Clinical Institute, Bucharest, Romania \\ ${ }^{3}$ Department of Oncology, , Fundeni Clinical Institute, Bucharest, Romania \\ ${ }^{4}$ Center of Gastroenterology and Hepatology, Fundeni Clinical Institute, Bucharest, Romania \\ ${ }^{5}$ Department of Pathology, Fundeni Clinical Institute, Bucharest, Romania \\ ${ }^{6}$ Department of Radiology, Fundeni Clinical Institute, Bucharest, Romania
}

Corresponding author: Razvan Grigorie, MD, PhD "Dan Setlacec" Center of General Surgery and Liver Transplantation Fundeni Clinical Institute, Bucharest Soseaua Fundeni, 258, sector 2 E-mail: mihai.grig@gmail.com

Abbreviations:

SCLMs - synchronous colorectal

liver metastases;

$\mathrm{SgR}$ - staged resections

$\mathrm{SR}$ - simultaneous resection;

Received: 1.03.2017

Accepted: 3.04 .2017

\section{Rezumat}

Analiza comparativă între rezecția simultană și rezecțiile seriate pentru metastaze hepatice colorectale sincrone - experiența a 300 de pacienti consecutivi operati într-un singur centru

Introducere: Rezecția simultană (SR) a tumorii colorectale şi a metastazelor hepatice sincrone (SCLMs) nu este utilizată pe scară largă. Majoritatea autorilor preferă încă rezecțiile seriate $(\mathrm{SgR})$, mai ales la pacientii cu cancer de rect sau care necesită efectuarea unei hepatectomii majore.

Material şi metodă: Ratele morbidității, mortalității şi supraviețuirii, precum şi durata medie a spitalizării au fost comparate între cele două grupuri (SR vs. SgR). De asemenea, aceşti parametri au fost comparați şi între diverse subgrupuri de pacienți cu caracteristici similare (tumoră de rect, hepatectomie majoră, metastaze bilobare, chimioterapie preoperatorie, etc).

Rezultate: Între 1995 şi 2016, la 234 de pacienți s-a practicat SR, iar la 66 de pacienți SgR. Ratele comparative ale morbidității (41\%, respectiv $31.8 \%, \mathrm{p}=0.1997)$, mortalitătii $(3.8 \%$, respectiv $3 \%$, $\mathrm{p}=1)$ şi supraviețuirii globale $(85.8 \%, 51.3 \%$ şi $30 \%$, respectiv $87 \%$, $49.6 \%$ şi $22.5 \%$, la 1-, 3 - şi 5 -years, $p=0.386$ ) nu au fost semnificativ 
statistic diferite între cele două grupuri (SR vs. SgR). Durata medie a spitalizării a fost semnificativ mai scurtă după SR decât după SgR $(15.11 \pm 8.60$, respectiv $19.42 \pm 7.36$ zile, p < 0.0001$)$. Caracteristicile celor două grupuri au fost similare, cu excepția următorilor parametri: localizarea rectală (mai frecventă în SR grup, p = 0.0245), inavazia ganglionară (mai frecventă în SgR grup, $p=0.0383$ ), metastaze bilobare (mai frecvente în SgR grup, $p=0.0169$ ), hepatectomii majore (mai frecvente în SgR grup, p = 0.025), chimioterapie neo-adjuvantă (mai frecvent în SgR grup, p < 0.0001). A fost efectuată o analiză comparativă a morbidității, mortalității şi supraviețuirii pentru fiecare din subgrupurile de pacienți prezentând aceste caracteristici. Pentru fiecare subgrup, SR a fost asociată cu rate similare ale morbidității, mortalității şi supraviețuirii ca şi SgR (p > 0.05).

Concluzii: La pacienții cu SCLMs, SR oferă rezultate pe termen scurt şi lung similare SgR şi o durată mai scurtă a spitalizării. Pentru majoritatea pacienților cu SCLMs, SR ar trebui considerată abordarea terapeutică de elecție.

Cuvinte cheie: sincron, cancer colorectal, metastaze hepatice, rezecție simultană, rezecție seriată, chimioterapie

\begin{abstract}
Introduction: In synchronous colorectal liver metastases (SCLMs), simultaneous resection (SR) of the primary tumor and liver metastases has not gained wide acceptance. Most authors prefer staged resections (SgR), especially in patients presenting rectal cancer or requiring major hepatectomy.

Methods: Morbidity, mortality, survival rates and length of hospital stay were compared between the two groups of patients (SR vs. SgR). A subgroup analysis was performed for patients with similar characteristics (e.g. rectal tumor, major hepatectomy, bilobar metastases, metastatic lymph nodes, preoperative chemotherapy).

Results: Between 1995 and 2016, SR was performed in 234 patients, while 66 patients underwent SgR. Comparative morbidity ( $41 \%$ vs. $31.8 \%$, respectively, p $=0.1997)$, mortality $(3.8 \%$ vs. $3 \%$, respectively, $\mathrm{p}=1$ ) and overall survival rates $(85.8 \%, 51.3 \%$ and $30 \%$ vs. $87 \%, 49.6 \%$ and $22.5 \%$, at $1^{-}, 3^{-}$and 5-years, respectively, $\left.\mathrm{p}=0.386\right)$ were similar between the $\mathrm{SR}$ and $\mathrm{SgR}$ group. Mean hospital stay was significantly shorter in patients undergoing SR than SgR (15.11 \pm 8.60 vs. 19.42 \pm 7.36 days, respectively, $\mathrm{p}<0.0001)$. The characteristics of $\mathrm{SR}$ and $\mathrm{SgR}$ groups were similar, except the following parameters: rectal tumor $(34.1 \%$ vs. $19.7 \%$, respectively, $\mathrm{p}=0.0245)$, metastatic lymph nodes $(68.1 \%$ vs. $86.3 \%$, respectively, $\mathrm{p}=0.0383)$, bilobar liver metastases $(22.6 \%$ vs. $37.8 \%$, respectively, $p=0.0169)$, major hepatectomies $(13.2 \%$ vs. $30.3 \%$, respectively, $p=0.0025)$ and neo-adjuvant chemotherapy ( $13.2 \%$ vs. $77.2 \%$, respectively, $\mathrm{p}<0.0001)$. A comparative analysis of morbidity, mortality and survival rates between SR and SgR was performed for subgroups of patients presenting these parameters. In each of these subgroups, SR was associated with similar morbidity, mortality and survival rates compared with SgR ( $p$ value $>0.05$ ).

Conclusion: In patients with SCLMs, SR provides similar short-term and long-term outcomes as SgR, with a shorter hospital stay. Therefore, in most patients with SCLMs, SR might be considered the treatment of choice.
\end{abstract}

Key words: synchronous, colorectal cancer, liver metastases, simultaneous resection, staged resection, chemotherapy

\section{Introduction}

Although the treatment of liver metastases from colorectal cancer is multimodal, the only potentially curative approach to these patients consists in complete resection of liver metas- 
tases (LM). In patients with synchronous colorectal metastases (SCLMs), the treatment should aim the curative resection of both primary tumor and LM. To achieve these objectives, three surgical approaches are available: 1. Simultaneous resection (SR) of colorectal cancer and LM; 2. Resection of the primary tumor followed by resection of LM (delayed liver resection - DR); 3. Initial hepatectomy and subsequent colorectal resection ("liver-first" approach).

Because SR implies association of two major operations during the same operative procedure, many authors were skeptical about the safety of this surgical approach to SCLMs. Simultaneous performance of colorectal resection and hepatectomy was considered to be associated with higher morbidity and mortality rates than staged resections (either DR or "liver-first" approach) (1,2). Moreover, most patients undergoing DR will receive chemotherapy during the interval between colorectal resection and liver resection $(3,4)$. Also, in "liver-first" approach the patients usually receive chemotherapy before hepatectomy (5). In patients whose LM progress during chemotherapy, liver resection is frequently abandoned because of the very low survival rates achieved by hepatectomy (5-year overall survival less than 8\%) (6). On the other hand, most of the patients who underwent SR did not receive chemotherapy before operation. Thus, it was hypothesized that staged resections (SgR) allow a better selection of patients than SR and this will translate in higher survival rates following $\mathrm{SgR}(3,7)$. However, these theoretical assumptions have been challenged during the last decade by the results reported by several centers experienced in colorectal and liver surgery (8-10).

Hereby, are presented the results achieved by $\mathrm{SR}$ and $\mathrm{SgR}$ in 300 consecutive patients with SCLMs, operated in a single center.

\section{Methods}

In "Dan Setlacec" Center of General Surgery and Liver Transplantation from Fundeni Clinical Institute, all the patients diagnosed with colorectal cancer who did not require emergency surgery, underwent preoperative contrast-enhanced abdominal CT scan or MRI to assess the presence of liver metastases. Whenever preoperative imaging could not rule out the presence of liver metastases, it was performed intraoperative ultrasonography during the operation addressed to the primary tumor. During colorectal resection all patients underwent intraoperative evaluation of the liver. Moreover, in patients requiring urgent operation caused by the complications of the colorectal tumor, who did not underwent preoperative CT scan or MRI, one of the afore mentioned investigations has been performed before discharging the patient.

The metastases that were diagnosed in this manner (preoperatively, during operation or during hospitalization after resection of the colorectal tumor) were considered as synchronous metastases. In the present study, there were retrospectively enrolled the first 300 consecutive patients who underwent curative intent resection of primary tumor and liver only synchronous metastases in "Dan Setlacec" Center of General Surgery and Liver Transplantation from Fundeni Clinical Institute, from 1995 to 2015. As well, the patients with initially unresectable SCLMs were excluded.

Out of the 300 patients, 234 underwent SR while 66 patients underwent SgR (61 patients with DR and 5 patients with "liver-first" approach).

The parameters that were evaluated were: age, gender, location of the primary tumor, $\mathrm{T}$ status and $\mathrm{N}$ status (according to the $7^{\text {th }}$ edition of TNM staging system), number and the largest size of liver metastases, distribution of liver metastases (unilobar vs. bilobar), chemotherapy before liver resection, extent of liver resection (minor vs. major hepatectomy), completeness of hepatectomy, estimated blood loss, number of patients receiving transfusion, total operative time and the length of hospital stay.

Total operative time represented the duration of the operation for patients undergoing SR. In patients who underwent SgR, the total operative time was calculated as the sum of the 
operative times of the two procedures. The length of hospital stay represents the days of hospitalization for patients undergoing SR and the sum of the days of hospital stay after colorectal resection and liver resection, in $\mathrm{SgR}$ patients.

The Mann-Whitney test was used to compare quantitative variables. A $p$ value below 0.05 was considered to be statistically significant.

Any complication that occurred during hospitalization or within 30 postoperative days (POD) was recorded and reported when the postoperative morbidity was calculated. For patients who underwent a SgR, complications were generated as the sum from colorectal and liver procedure. Mortality was calculated taking into account any death occurring during hospitalization after liver resection or within 30 days after hepatectomy.

The morbidity and mortality rates between different groups of patients were compared with Chi-square test or Fischer exact test. The difference was considered statistically significant when $\mathrm{p}$ value $<0.05$.

The survival was defined as the interval between the liver resection and the last followup or the date of patient's decease. The 1-, $3^{-}$ and 5-year overall survival rates and the median survival were estimated with KaplanMeyer test. The survival rates between different groups of patients were compared with Log-rank test. When the $\mathrm{p}^{-}$value was lower than 0.05, the difference was considered statistically significant.

In patients undergoing SR, neo-adjuvant chemotherapy was delivered before resection of the primary tumor and liver metastases. In patients who underwent SgR, it was delivered either during the interval between colorectal resection and liver resection (in DR), or before hepatectomy in patients undergoing "liverfirst approach".

\section{Results}

\section{Characteristics of the SR Group and SgR Group}

The comparative analysis of the two groups
(SR group and SgR group, respectively), revealed that age, gender, T-stage, number and size of SCLMs, completeness of liver resection, estimated blood loss and the number of patients who required transfusion were similarly distributed in the two groups (Table 1). However, some characteristics related to the primary tumor, liver metastases, surgical procedure and oncologic treatment were significantly different between the two groups (Table 1).

\section{Primary Tumor}

In the SR group, significantly more patients had a rectal tumor than in the SgR group $(34.1 \%$ vs. $19.6 \%$, p value $=0.0245)$.

The proportion of patients without lymphnodes metastases (N0) was significantly higher in SR group than in SgR group (31.8\% vs. $13.6 \%$, $p$ value $=0.0383$.

\section{Liver Metastases}

Regarding the distribution of SCLMs, the bilobar involvement of the liver was more frequent in the SgR group than in the SR group $(37.8 \%$ vs. $22.6 \%$, p value $=0.0169)$.

\section{Operative Procedure}

Major hepatectomy was significantly more frequently performed in SgR group, comparative with the number of patients undergoing major liver resection in SR group (30.3\% vs. $13.2 \%$, $p$ value $=0.0025$.

In the SgR group, the mean total operative time was $315.405 \pm 76.634$ minutes (median 320 minutes), while in patients undergoing SR, the mean operative time was $229.414 \pm$ 100.47 minutes (median 200 minutes). The duration of operative time was highly significant longer in SgR group than in SR group ( $p$ value $<0.0001$ )

The mean lengths of hospital stay was statistically significant longer in SgR group than in SR group (19.421 \pm 7.363 days vs. 15.111 \pm 8.604 days, $p$ value $<0.0001$; median 18 vs. 12 days).

\section{Oncologic Treatment}

A significantly higher number of patients underwent neo-adjuvant chemotherapy in 
Table 1. Comparative analysis of patients' characteristics in SR group and $\mathrm{SgR}$ group

\begin{tabular}{|c|c|c|c|}
\hline & $S R(n=234)$ & $\operatorname{SgR}(n=66)$ & $p$ value \\
\hline $\begin{array}{l}\text { Age (year-old) } \\
\text { Median (mean } \pm S D)\end{array}$ & $\begin{array}{c}62 \\
(60.659 \pm 10.528)\end{array}$ & $\begin{array}{c}59 \\
(59.075 \pm 9.097)\end{array}$ & 0.1601 \\
\hline $\begin{array}{l}\text { Gender } \\
\text { Male } \\
\text { Female }\end{array}$ & $\begin{array}{l}132 \\
102\end{array}$ & $\begin{array}{l}35 \\
31\end{array}$ & 0.6747 \\
\hline $\begin{array}{l}\text { Primary } \\
\text { Colon } \\
\text { Rectum }\end{array}$ & $\begin{array}{c}154 \\
80\end{array}$ & $\begin{array}{l}53 \\
13\end{array}$ & 0.0245 \\
\hline $\begin{array}{l}\text { T stage }^{*} \\
\text { T1-T3 } \\
\text { T4 }\end{array}$ & $\begin{array}{l}187 \\
31\end{array}$ & $\begin{array}{c}42 \\
6\end{array}$ & 1 \\
\hline $\begin{array}{c}\text { N stage } \\
\text { N0 } \\
\text { N1 } \\
\text { N2 }\end{array}$ & $\begin{array}{l}63 \\
58 \\
77\end{array}$ & $\begin{array}{c}6 \\
19 \\
19\end{array}$ & 0.0383 \\
\hline $\begin{array}{l}\text { Extent of LR } \\
\text { Minor } \\
\text { Major }\end{array}$ & $\begin{array}{c}203 \\
31\end{array}$ & $\begin{array}{l}46 \\
20\end{array}$ & 0.0025 \\
\hline $\begin{array}{c}\text { No of SCLMs } \\
1 \\
2-3 \\
>=4\end{array}$ & $\begin{array}{c}137 \\
70 \\
27\end{array}$ & $\begin{array}{l}28 \\
26 \\
12\end{array}$ & 0.0600 \\
\hline $\begin{array}{l}\text { SCLMs diameter } \\
\quad<5 \mathrm{~cm} \\
>5 \mathrm{~cm}\end{array}$ & $\begin{array}{c}168 \\
66\end{array}$ & $\begin{array}{l}39 \\
27\end{array}$ & 0.0519 \\
\hline $\begin{array}{l}\text { Distribution } \\
\text { Unilobar } \\
\text { Bilobar }\end{array}$ & $\begin{array}{l}181 \\
53\end{array}$ & $\begin{array}{l}41 \\
25\end{array}$ & 0.0169 \\
\hline $\begin{array}{l}\text { Preoperative chemo } \\
\text { Yes } \\
\text { No }\end{array}$ & $\begin{array}{c}31 \\
203\end{array}$ & $\begin{array}{l}51 \\
15\end{array}$ & $<0.0001$ \\
\hline $\begin{array}{l}\text { Operative time (min) } \\
\text { Median (mean } \pm \text { SD) }\end{array}$ & $\begin{array}{c}200 \\
(229.414 \pm 100.47)\end{array}$ & $\begin{array}{c}320 \\
(315.405 \pm 76.634)\end{array}$ & $<0.0001$ \\
\hline $\begin{array}{l}\text { Blood loss (ml) } \\
\text { Median (mean } \pm \text { SD) }\end{array}$ & $\begin{array}{c}300 \\
(557.547 \pm 731.66)\end{array}$ & $\begin{array}{c}225 \\
(308.333 \pm 178.16)\end{array}$ & 0.3498 \\
\hline $\begin{array}{l}\text { Incomplete resections } \\
\text { (R1/R2) }\end{array}$ & 1 & 마이 & 1 \\
\hline Patients receiving RBP & 46 & 11 & 0.7227 \\
\hline $\begin{array}{l}\text { Length of hospital stay (days) } \\
\text { Median (mean } \pm \text { SD) }\end{array}$ & $\begin{array}{c}12 \\
(15.111 \pm 8.604)\end{array}$ & $\begin{array}{c}18 \\
(19.421 \pm 7.363)\end{array}$ & $<0.0001$ \\
\hline
\end{tabular}

* Missing data in 34 patients; ** Missing data in 58 patients

SgR group, than in the SR group $(77.2 \%$ vs. $13.2 \%, \mathrm{p}$ value $=0.0245$ )

\section{Morbidity Rates}

In the SR group, the morbidity rate was $41 \%$ (96/234 patients), while in SgR group, 21 patients $(31.8 \%)$ developed complications. The difference was not statistically significant $(\mathrm{p}$ value $=0.1997)$
Among the patients with rectal tumors undergoing SR, the morbidity rate was, not statistically significant higher than those observed in patients with rectal tumors who underwent SgR (45\% vs. $30.7 \%$, respectively; $\mathrm{p}$ value $=0.3825)$.

As well, in patients undergoing major hepatectomy and simultaneous resection of the primary tumor, the morbidity rate was similar to that observed in patients undergoing major 
hepatectomy as part of a staged procedure $(45.1 \%$ vs. $45 \%$, respectively; $p$ value $=1)$.

Similarly, the presence of multiple SCLMs, the bilobar distribution of metastases, neoadjuvant chemotherapy or other characteristics of tumors and therapy did not significantly increase the morbidity rates in SR group vs. SgR group ( $\mathrm{p}$ value $>0.05$ ) (Table 2).

\section{Mortality Rates}

In the SR group, 9 patients deceased postoperatively (3.8\%), while in the SgR group, the mortality rate was $3 \%$ (2/66 patients). The difference was not statistically significant $(p$ value $=1)$.

One patient with rectal tumor deceased after SR (1.2\%), whereas no death occurred among patients with rectal cancer and SCLMs who underwent a staged procedure. The mortality rates of patients with primary tumors confined to the rectum were similar in the SR group and SgR group ( $p$ value $=1)$.

In patients requiring major hepatectomies for their SCLMs, the mortality rate in SR group was similar to those achieved in $\mathrm{SgR}$ group $(6.4 \%$ vs. $5 \%$, respectively; p value $=1)$.

Mortality rates of patients with multiple SCLMs were similar among the two groups of patients $(\mathrm{p}$ value $=1)$; in SR group the mortality rate was $6.4 \%$ (5/97 patients), while in the $\mathrm{SgR}$ group it was $5.2 \%$ (2/38 patients).

When bilobar SCLMs were present, the mortality rates were similar in the SR group and SgR group (1.8\% vs. 0\%, respectively; $\mathrm{p}$ value $=1$ ).

In patients undergoing neo-adjuvant chemotherapy, SR was associated with similar mortality as SgR (0\% vs. $1.9 \%$, respectively; $\mathrm{p}$ value $=1$ )

Also in the other subgroups of patients the mortality rates were similar after SR and SgR, respectively ( $\mathrm{p}$ value $>0.05$ ) (Table 3 ).

\section{Overall Survival}

In patients undergoing SR the $1^{-}, 3^{-}, 5^{-}$and 10 -year OS rates were $85.8 \%, 51.3 \%, 30 \%$ and $15.3 \%$, respectively. The median survival
Table 2. Comparative morbidity rates between $\mathrm{SR}$ and $\mathrm{SgR}$ (for the entire groups and subgroups)

\begin{tabular}{|c|c|c|c|}
\hline & $\begin{array}{c}\text { SR } \\
n=234\end{array}$ & $\begin{array}{c}\mathrm{SgR} \\
\mathrm{n}=66\end{array}$ & $p$ value \\
\hline Total number & 96 & 21 & 0,1997 \\
\hline \multicolumn{4}{|l|}{ Gender } \\
\hline Female & $37 / 102$ & $7 / 31$ & 0.193 \\
\hline Male & $59 / 132$ & $14 / 35$ & 0.7030 \\
\hline \multicolumn{4}{|l|}{ Location } \\
\hline Colon & $60 / 154$ & $17 / 53$ & 0.4130 \\
\hline Rectum & $36 / 80$ & $4 / 13$ & 0.3825 \\
\hline \multicolumn{4}{|l|}{ T stage } \\
\hline $\mathrm{T} 1-\mathrm{T} 3$ & $79 / 187$ & $12 / 42$ & 0.1179 \\
\hline $\mathrm{T} 4$ & $6 / 31$ & $2 / 6$ & 0.5913 \\
\hline \multicolumn{4}{|l|}{$\mathrm{N}$-stage } \\
\hline NO & $27 / 63$ & $1 / 6$ & 0.3894 \\
\hline N1 & $20 / 58$ & $8 / 19$ & 0.5900 \\
\hline N2 & $37 / 77$ & $5 / 19$ & 0.1218 \\
\hline \multicolumn{4}{|c|}{ Extent of liver resection } \\
\hline Minor & $82 / 203$ & $12 / 46$ & 0.0916 \\
\hline Major & $14 / 31$ & $9 / 20$ & 1 \\
\hline \multicolumn{4}{|l|}{ Nr of SCLMs } \\
\hline 1 & $51 / 137$ & $8 / 28$ & 0.5169 \\
\hline $2-3$ & $35 / 70$ & $8 / 26$ & 0.1098 \\
\hline$>=4$ & $10 / 27$ & $5 / 12$ & 1 \\
\hline \multicolumn{4}{|c|}{ SCLMs diameter } \\
\hline$<5 \mathrm{~cm}$ & $67 / 168$ & $12 / 39$ & 0.3613 \\
\hline$>5 \mathrm{~cm}$ & $29 / 66$ & $9 / 27$ & 0.3654 \\
\hline \multicolumn{4}{|l|}{ Distribution } \\
\hline Unilobar & $75 / 181$ & $14 / 41$ & 0.4809 \\
\hline Bilobar & $21 / 53$ & $7 / 25$ & 0.4487 \\
\hline \multicolumn{4}{|c|}{ Preoperative chemo } \\
\hline Yes & $13 / 31$ & $16 / 51$ & 0.3512 \\
\hline No & $83 / 203$ & $5 / 15$ & 0.7860 \\
\hline
\end{tabular}

following SR was 39 months. In SgR group, the OS rates at $1^{-}, 3^{-}, 5^{-}$and 10 -year were $87 \%$, $49.6 \%, 22.5 \%$ and $12.5 \%$, respectively, with a median survival of 35 months. The difference between OS achieved by SR and SgR, respectively, was not statistical significantly different $(\mathrm{p}$ value $=0.386)$. Comparative survival curves are displayed in Fig. 1.

In patients with rectal tumors and SCLMs who underwent SR, the 1-, 3- and 5-year OS rates were not significantly lower than those achieved by $\operatorname{SgR}(91.2 \%, 50 \%$ and $28.2 \%$, vs. $76.9 \%, 56.1 \%$ and $28 \%$, respectively; $\mathrm{p}$ value $=$ $0.317)$.

The OS rates achieved by SR in patients 
Table 3. Comparative mortality rates between $\mathrm{SR}$ and $\mathrm{SgR}$ (for the entire groups and subgroups)

\begin{tabular}{lccc}
\hline & $\begin{array}{c}\text { SR } \\
\mathbf{n}=\mathbf{2 3 4}\end{array}$ & $\begin{array}{c}\text { SgR } \\
\mathbf{n}=\mathbf{6 6}\end{array}$ & p value \\
\hline Total number & 9 & 2 & 1 \\
\hline $\begin{array}{c}\text { Location } \\
\text { Colon }\end{array}$ & $8 / 154$ & $2 / 53$ & 1 \\
\hline Rectum & $1 / 80$ & $0 / 13$ & 1 \\
\hline $\begin{array}{c}\text { Extent of liver resection } \\
\text { Minor }\end{array}$ & $7 / 203$ & $1 / 46$ & 1 \\
\hline Major & $2 / 31$ & $1 / 20$ & 1 \\
\hline $\begin{array}{c}\text { Nr of SCLMs } \\
1\end{array}$ & $4 / 137$ & $0 / 28$ & 1 \\
\hline$>=2$ & $5 / 97$ & $2 / 38$ & 1 \\
\hline $\begin{array}{c}\text { SCLMs diameter } \\
<5 \text { cm }\end{array}$ & $6 / 168$ & $1 / 39$ & 1 \\
\hline$>5 c m$ & $3 / 66$ & $1 / 27$ & 1 \\
\hline Distribution \\
Unilobar
\end{tabular}

with SCLMs and lymph nodes metastases $(\mathrm{N} 1, \mathrm{~N} 2)$ were not lower than those achieved by SgR ( $p$ value $>0.05$ ). In patients presenting metastases in 1-3 lymph nodes (N1), the $1^{-}, 3^{-}$ and 5-year OS rates achieved by SR and SgR $(87.7 \%, 47.1 \%$ and $31 \%$ vs. $94.4 \%, 63.6 \%$ and $28.3 \%$, respectively) were not significantly different $(\mathrm{p}$ value $=0.559)$. As well, in SR group, the 1-, 3- and 5-year OS rates achieved by patients presenting at least 4 metastatic lymph nodes (N2) were not lower than those observed in similar patients undergoing $\mathrm{SgR}$ $(81.5 \%, 42.3 \%$ and $21.2 \%$ vs. $87.8 \%, 36.9 \%$ and $12.3 \%$, respectively; $p$ value $=0.447)$.

When bilobar metastases were present, the performance of SgR did not improve OS comparative with SR $(81 \%, 27.8 \%$ and $13.9 \%$ vs. $80 \%, 36.1 \%$ and $20 \%$, at $1-$ - $3-$ and 5 -year, respectively; $\mathrm{p}$ value $=0.380)$.

In patients with multiple SCLMs, the OS rates achieved by SR were also similar to those achieved by SgR ( $p$ value $>0.05$ ).

For each subgroup of patients that was analyzed, SR provided OS rates comparable to SgR (Table 4).

\section{Discussion}

Historically, the first surgical approach to SCLMs was DR, whose initial results were published in the late " $80 \mathrm{~s}$ (4). In this procedure, after resection of primary tumor, the patients

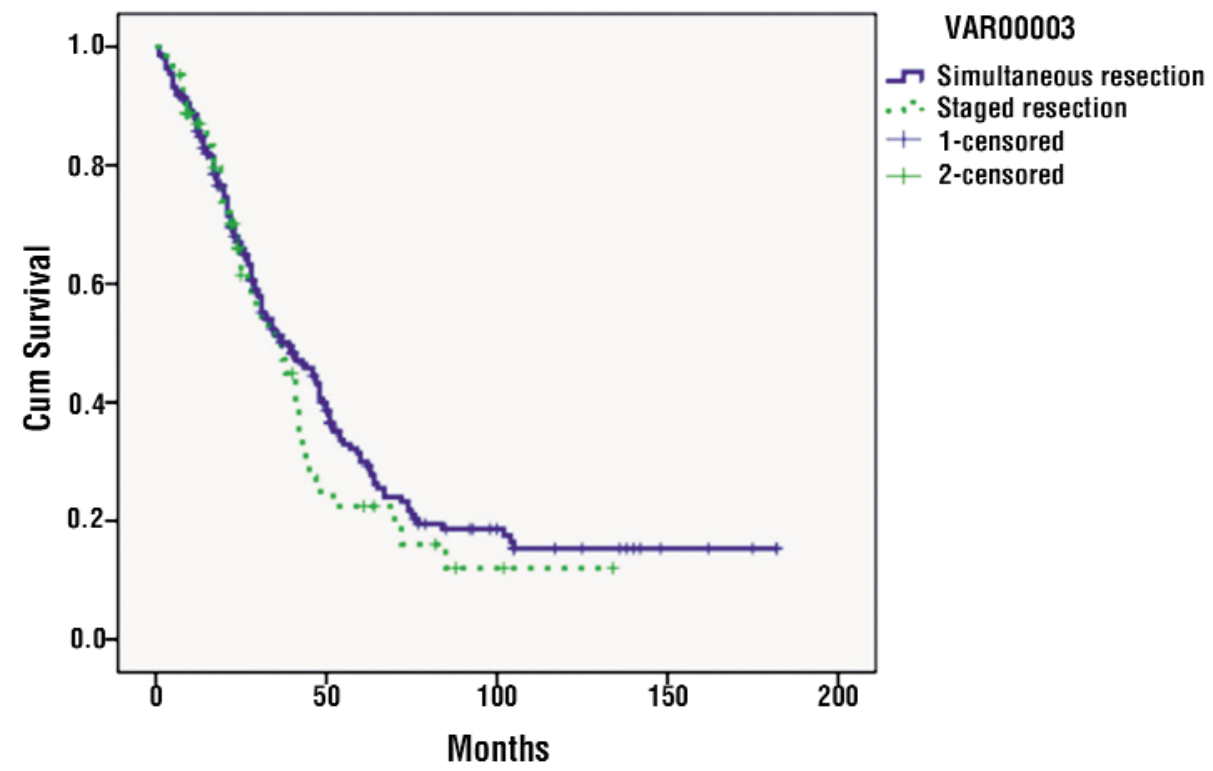

Figure 1. Comparative overall survival between SR and SgR 
Table 4. Comparative overall survival rates between $\mathrm{SR}$ and $\mathrm{SgR}$

\begin{tabular}{|c|c|c|c|c|c|c|c|c|c|}
\hline & \multicolumn{4}{|c|}{ Simultaneous resection } & \multicolumn{4}{|c|}{ Staged resection } & \multirow[t]{2}{*}{$p$ value } \\
\hline & $1-\mathrm{yr}$ & $3-y r$ & $5-y r$ & Median & $1-\mathrm{yr}$ & $3-y r$ & $5-y r$ & Median & \\
\hline Entire groups & $85.8 \%$ & $51.3 \%$ & $30 \%$ & $39 \mathrm{mo}$ & $87 \%$ & $49.6 \%$ & $22.5 \%$ & $35 \mathrm{mo}$ & 0.386 \\
\hline $\begin{array}{l}\text { Gender } \\
\text { Female } \\
\text { Male }\end{array}$ & $\begin{array}{l}88.6 \% \\
83.6 \%\end{array}$ & $\begin{array}{c}53 \% \\
50.1 \%\end{array}$ & $\begin{array}{l}27.7 \% \\
33.4 \%\end{array}$ & $\begin{array}{l}41 \mathrm{mo} \\
37 \mathrm{mo}\end{array}$ & $\begin{array}{c}92.6 \% \\
82 \%\end{array}$ & $\begin{array}{l}40.2 \% \\
60.5 \%\end{array}$ & $\begin{array}{l}26.8 \% \\
16.8 \%\end{array}$ & $\begin{array}{l}31 \mathrm{mo} \\
41 \mathrm{mo}\end{array}$ & $\begin{array}{l}0.688 \\
0.390\end{array}$ \\
\hline $\begin{array}{l}\text { Location } \\
\text { Colon } \\
\text { Rectum }\end{array}$ & $\begin{array}{l}82.7 \% \\
91.2 \%\end{array}$ & $\begin{array}{c}52.2 \% \\
50 \%\end{array}$ & $\begin{array}{l}30.8 \% \\
28.2 \%\end{array}$ & $\begin{array}{l}40 \mathrm{mo} \\
35 \mathrm{mo}\end{array}$ & $\begin{array}{l}89.6 \% \\
76.9 \%\end{array}$ & $\begin{array}{l}50.4 \% \\
56.1 \%\end{array}$ & $\begin{array}{c}22.5 \% \\
28 \%\end{array}$ & $\begin{array}{l}37 \mathrm{mo} \\
47 \mathrm{mo}\end{array}$ & $\begin{array}{l}0.535 \\
0.317\end{array}$ \\
\hline $\begin{array}{l}\text { T-stage } \\
\text { T1-T3 } \\
\text { T4 }\end{array}$ & $\begin{array}{l}85.7 \% \\
87.5 \%\end{array}$ & $\begin{array}{l}50.3 \% \\
61.7 \%\end{array}$ & $\begin{array}{c}30.1 \% \\
31 \%\end{array}$ & $\begin{array}{l}37 \mathrm{mo} \\
46 \mathrm{mo}\end{array}$ & $\begin{array}{l}84.5 \% \\
100 \%\end{array}$ & $\begin{array}{c}49.4 \% \\
60 \%\end{array}$ & $\begin{array}{c}21.2 \% \\
40 \%\end{array}$ & $\begin{array}{l}31 \mathrm{mo} \\
37 \mathrm{mo}\end{array}$ & $\begin{array}{l}0.363 \\
0.596\end{array}$ \\
\hline $\begin{array}{l}\text { N-stage } \\
\text { N0 } \\
\text { N1 } \\
\text { N2 }\end{array}$ & $\begin{array}{l}93.7 \% \\
87.7 \% \\
81.5 \%\end{array}$ & $\begin{array}{l}65.7 \% \\
47.1 \% \\
42.3 \%\end{array}$ & $\begin{array}{c}42.2 \% \\
31 \% \\
21.2 \%\end{array}$ & $\begin{array}{l}51 \mathrm{mo} \\
32 \mathrm{mo} \\
31 \mathrm{mo}\end{array}$ & $\begin{array}{l}66.7 \% \\
94.4 \% \\
87.8 \%\end{array}$ & $\begin{array}{l}22.2 \% \\
63.6 \% \\
36.9 \%\end{array}$ & $\begin{array}{l}22.2 \% \\
28.3 \% \\
12.3 \%\end{array}$ & $\begin{array}{l}22 \mathrm{mo} \\
43 \mathrm{mo} \\
24 \mathrm{mo}\end{array}$ & $\begin{array}{l}0.232 \\
0.559 \\
0.447\end{array}$ \\
\hline $\begin{array}{l}\text { Extent of liver resection } \\
\text { Minor } \\
\text { Major }\end{array}$ & $\begin{array}{l}85.3 \% \\
89.1 \%\end{array}$ & $\begin{array}{c}51.6 \% \\
45 \%\end{array}$ & $\begin{array}{l}31.1 \% \\
22.5 \%\end{array}$ & $\begin{array}{l}39 \mathrm{mo} \\
31 \mathrm{mo}\end{array}$ & $\begin{array}{l}92.8 \% \\
72.2 \%\end{array}$ & $\begin{array}{l}50.4 \% \\
48.8 \%\end{array}$ & $\begin{array}{l}20.2 \% \\
29.3 \%\end{array}$ & $\begin{array}{l}37 \mathrm{mo} \\
35 \mathrm{mo}\end{array}$ & $\begin{array}{l}0.356 \\
0.981\end{array}$ \\
\hline $\begin{array}{l}\text { Nr. of SCLMS } \\
\begin{array}{l}1 \\
2-3 \\
>=4\end{array}\end{array}$ & $\begin{array}{l}89.2 \% \\
77.8 \% \\
88.5 \%\end{array}$ & $\begin{array}{l}57.6 \% \\
44.8 \% \\
35.1 \%\end{array}$ & $\begin{array}{l}35.8 \% \\
24.7 \% \\
8.8 \%\end{array}$ & $\begin{array}{l}46 \mathrm{mo} \\
31 \mathrm{mo} \\
28 \mathrm{mo}\end{array}$ & $\begin{array}{c}92.9 \% \\
86.7 \% \\
70 \%\end{array}$ & $\begin{array}{l}56.1 \% \\
58.2 \% \\
11.7 \%\end{array}$ & $\begin{array}{l}28.3 \% \\
19.4 \% \\
11.7 \%\end{array}$ & $\begin{array}{l}41 \mathrm{mo} \\
41 \mathrm{mo} \\
17 \mathrm{mo}\end{array}$ & $\begin{array}{l}0.650 \\
0.723 \\
0.155\end{array}$ \\
\hline $\begin{array}{l}\text { SCLMs diameter } \\
\quad<5 \mathrm{~cm} . \\
>5 \mathrm{~cm} .\end{array}$ & $\begin{array}{l}88.7 \% \\
77.9 \%\end{array}$ & $\begin{array}{l}56.8 \% \\
37.6 \%\end{array}$ & $\begin{array}{l}33.4 \% \\
21.7 \%\end{array}$ & $\begin{array}{l}46 \mathrm{mo} \\
27 \mathrm{mo}\end{array}$ & $\begin{array}{l}86.3 \% \\
87.5 \%\end{array}$ & $\begin{array}{l}54.7 \% \\
42.8 \%\end{array}$ & $\begin{array}{l}25.2 \% \\
18.3 \%\end{array}$ & $\begin{array}{l}38 \mathrm{mo} \\
31 \mathrm{mo}\end{array}$ & $\begin{array}{l}0.348 \\
0.812\end{array}$ \\
\hline $\begin{array}{l}\text { Distribution } \\
\text { Unilobar } \\
\text { Bilobar }\end{array}$ & $\begin{array}{c}87.5 \% \\
80 \%\end{array}$ & $\begin{array}{l}55.9 \% \\
36.1 \%\end{array}$ & $\begin{array}{l}33 \% \\
20 \%\end{array}$ & $\begin{array}{l}46 \mathrm{mo} \\
29 \mathrm{mo}\end{array}$ & $\begin{array}{l}90 \% \\
81 \%\end{array}$ & $\begin{array}{l}60.9 \% \\
27.8 \%\end{array}$ & $\begin{array}{l}26.9 \% \\
13.9 \%\end{array}$ & $\begin{array}{l}41 \mathrm{mo} \\
20 \mathrm{mo}\end{array}$ & $\begin{array}{l}0.812 \\
0.380\end{array}$ \\
\hline $\begin{array}{l}\text { Preoperative chemo } \\
\text { Yes } \\
\text { No }\end{array}$ & $\begin{array}{l}92.6 \% \\
85.9 \%\end{array}$ & $\begin{array}{l}44.7 \% \\
52.4 \%\end{array}$ & $\begin{array}{l}38.3 \% \\
29.1 \%\end{array}$ & $\begin{array}{l}29 \mathrm{mo} \\
40 \mathrm{mo}\end{array}$ & $\begin{array}{c}91.3 \% \\
72 \%\end{array}$ & $\begin{array}{c}50.1 \% \\
37 \%\end{array}$ & $\begin{array}{l}25.2 \% \\
12.3 \%\end{array}$ & $\begin{array}{l}38 \mathrm{mo} \\
27 \mathrm{mo}\end{array}$ & $\begin{array}{l}0.919 \\
0.266\end{array}$ \\
\hline
\end{tabular}

underwent chemotherapy and subsequently, if SCLMs did not progress, liver resection was performed (3). These early reports had a tremendous contribution to the improvement of life-expectancy of patients with SCLMs, because it was revealed that complete resection of synchronous liver metastases from colorectal cancer represents a worthwhile operation which significantly increase survival of these patients $(3,4)$. During the ' $90 \mathrm{~s}$, due to the progresses in liver surgery and anesthetic management of patients undergoing hepatectomies, the safety of liver resection increased $(11,12)$. Thus, some centers decided to proceed with concomitant resection of both primary tumor and SCLMs (13). However, this strategy (called SR) raised many concerns related to the safety of the procedure, as well as to its oncologic benefit. Because these issues were not clearly elucidated, a novel staged approach to SCLMs was launched in 2006 by Gilles Mentha et al., aiming to avoid the hypothetical higher risks of SR and improve the oncologic outcome of these patients (5). This new onco-surgical strategy called "liver-first" approach consists in neoadjuvant chemotherapy followed by initial liver resection and subsequent colorectal resection. In present, a consensus regarding the indications of each approach (SR or SgR) has not been reached, especially in patients with rectal tumors or requiring major liver resections.

The present study revealed that the morbidity and mortality rates associated with SR are not significantly higher than those observed after SgR. Although similar results have been reported by our group and other recent studies (13-16), consensus conferences from 2012 and 2015 still recommended the 
avoidance of SR in patients with rectal cancer or in those requiring a major hepatectomy $(17,18)$. These recommendations (strength of evidence - level C) are based on the results of retrospective studies and reviews $(1,2,19)$. Moreover, these studies included small number of patients with rectal primaries or major hepatectomies in the SR groups.

In this study, almost one third (80/234) of the patients undergoing SR presented rectal tumors. Because the proportion of patients with rectal tumors was significantly higher in the SR group than in SgR group, a direct comparison between patients with rectal cancer who underwent SR vs. SgR was performed. The morbidity and mortality rates after SR of rectal tumor and liver metastases were not significantly higher than in patients with synchronous liver metastases from rectal cancer who underwent SgR. These results, consistent with similar recent reports on this subject $(9,20)$, confirm that even when the primary tumor is confined to the rectum, the SR could be safely performed in selected patients, treated in high-volume centers.

Because in this study, major liver resection was more frequently performed in SgR group, it was performed a comparative analysis between patients undergoing major hepatectomy by simultaneous or staged approaches. The morbidity and mortality rates of patients undergoing resection of 3 or more liver segments were similar irrespective the timing of primary tumor resection (simultaneous or staged; $p$ value $=1$ ). Similar short-term outcomes after simultaneous major liver resections were reported in the last decade by other authors $(15,21,22)$, challenging the paradigm that SR should be avoided when major hepatectomies are needed.

Nowadays it is well known that the only predictors of both morbidity and mortality after liver surgery are blood loss and the number of resected liver segments (23). In this study the blood loss was comparable in the SR group and SgR group $(557.547 \pm 731.66 \mathrm{ml}$ vs. $308.333 \pm$ $178.16 \mathrm{ml}, \mathrm{p}$ value $=0.3498$ ), thus explaining the similar morbidity and mortality rates observed in the two groups. Therefore, reduction in blood loss is responsible for the decrease in morbidity and mortality, despite the performance of concomitant procedures.

Another criticism addressed to the SR is the impossibility to select the patients, due to the lack of observation period before liver resection $(3,24,25)$. It was considered that chemotherapy administered before liver resection (neo-adjuvant chemotherapy) will allow a better understanding of tumor biology. Thus, if SCLMs will progress during chemotherapy, the liver resection is considered futile, because tumor progression before surgery is associated with poor outcomes (5-year OS rates lower than 8\%) (6). Therefore, traditionally, SgR used to be considered better than SR in terms of survival rates $(3,26)$.

In this series, the OS rates achieved by SR were higher than those achieved by $\mathrm{SgR}$, although the difference was not statistically significant. In the last years, several series revealed that OS rates achieved by SR were not significantly lower than those achieved by SgR (10,13,27-29). Moreover, in several large series it was observed that neo-adjuvant chemotherapy did not improve OS and disease-free survival in patients with SCLMs (30,31). These results could be explained by the fact that in the era of modern chemotherapy, the progression-free survival rates are longer than 6 months (32). Thus, it is unlikely to assess the tumor biology during an observation interval shorter than 6 months. By these reasons, some authors consider that the traditional paradigms of SCLMs management should be reconsidered, as long as neo-adjuvant chemotherapy did not bring any survival advantage in majority of patients with SCLMs $(32,33)$. In a recent paper, Ayez et al. suggested that neo-adjuvant chemotherapy might be beneficial only in patients whose clinical risk score ranges between 3 and 5 (34). Corroborating this result with the observation presented by Tanaka et al. who reported a survival advantage in patients with multiple and bilobar SCLMs undergoing neo-adjuvant chemotherapy, it seems that SgR could improve survival in high-risk patients (35). However, in the series presented here, the survival rates achieved by SgR were not significantly higher than those achieved by SR, 
either in patients with bilobar SCLMs or in those with multiple metastases. Until the results of ongoing randomized clinical trials (36) will be available, the neo-adjuvant chemotherapy could not be considered as therapeutic standard in patients with SCLMs and the superior oncologic outcomes of SgR over SR cannot be sustained.

The results of the present study suggest that SR can be safely performed in most patients with SCLMs and the oncologic outcomes of this approach are not inferior to those achieved by SgR.

The length of hospital stay was also significantly shorter after SR than following SgR, similar results being reported by other authors $(1,28,37)$. By reducing the hospital stay and sparing one hospitalization, it is obvious that comfort of the patient increases and the exposure to pathogens decreases (10). Moreover, the shorter operative time and length of hospitalization associated with SR will lead to a lower cost to health care system, optimizing economic outcomes of surgical therapy for patients with SCLMs (38).

\section{Conclusion}

In summary, the results of this study reveal that SR of colorectal cancer and synchronous metastases offers similar short- and long-term outcomes as $\mathrm{SgR}$, in patients treated in a high-volume center, with large expertise in liver and colorectal surgery. In experienced institutions, low morbidity and mortality rates could be achieved by SR, even in patients with rectal primaries or requiring major hepatectomies. The SR enables a shorter hospital stay, improving the comfort of the patient and reducing the costs for the health care system.

\section{References}

1. Hillingso JG, Wille-Jorgensen P. Staged or simultaneous resection of synchronous liver metastases from colorectal cancer--a systematic review. Colorectal Dis 2009;11(1):3-10.

2. Tanaka K, Shimada H, Matsuo K, Nagano Y, Endo I, Sekido H, et al. Outcome after simultaneous colorectal and hepatic resection for colorectal cancer with synchronous metastases. Surgery 2004; 136 (3):650-9.

3. Belghiti J. Métastases hépatiques synchrones et resecables des cancers colorectaux: y a-t-il un délai minimum a respecter avant de faire la résection hépatique. Ann Chir 1990;44(6):427-9.

4. Bismuth H, Castaing D, Traynor O. Surgery for synchronous hepatic metastases of colorectal cancer. Scand J Gastroenterol Suppl. 1988; 149:144-9.

5. Mentha G, Majno PE, Andres A, Rubbia-Brandt L, Morel P, Roth AD. Neoadjuvant chemotherapy and resection of advanced synchronous liver metastases before treatment of the colorectal primary. Br J Surg 2006;93(7):872-8.

6. Adam R, Pascal G, Castaing D, Azoulay D, Delvart V, Paule B, et al. Tumor progression while on chemotherapy: a contraindication to liver resection for multiple colorectal metastases? Ann Surg 2004; 240 (6):1052-61.

7. Nordlinger B, Guiguet M, Vaillant JC, Balladur P, Boudjema K, Bachellier $\mathrm{P}$, et al. Surgical resection of colorectal carcinoma metastases to the liver. A prognostic scoring system to improve case selection, based on 1568 patients. Association Francaise de Chirurgie. Cancer 1996;77(7):1254-62.

8. Jaeck D, Bachellier P, Weber JC, Mourad M, Walf P, Boudjema K. Le traitement chirurgical des métastases hépatiques synchrones des cancers colorectaux. Résection simultanée ou résection différée? Ann Chir 1996:50(7):507-12.

9. Silberhumer GR, Paty PB, Temple LK, Araujo RL, Denton B, Gonen M, et al. Simultaneous resection for rectal cancer with synchronous liver metastasis is a safe procedure. Am J Surg 2015; 209(6):935-42.

10. Silberhumer GR, Paty PB, Denton B, Guillem J, Gonen M, Araujo RL, et al. Long-term oncologic outcomes for simultaneous resection of synchronous metastatic liver and primary colorectal cancer. Surgery 2016;160(1):67-73.

11. Belghiti J, Hiramatsu K, Benoist S, Massault P, Sauvanet A, Farges 0 . Seven hundred forty-seven hepatectomies in the 1990s: an update to evaluate the actual risk of liver resection. J Am Coll Surg 2000; 191(1):38-46

12. Steele G Jr, Ravikumar TS. Resection of hepatic metastases from colorectal cancer. Biologic perspective. Ann Surg 1989;210(2):127-38.

13. Jaeck D, Bachellier P, Weber JC, Boudjema K, Mustun A, Paris F, et al. Stratégie chirurgicale dans le traitement des métastases hépatiques synchrones des cancers colorectaux. Analyse d'une série de 59 malades opérés. Chirurgie 1999;124(3):258-63.

14. Alexandrescu S, Hrehoret D, Ionel Z, Croitoru A, Anghel R, Popescu I. Simultaneous resection of the primary colorectal tumor and liver metastases - a safe and effective operation. Chirurgia (Bucur) 2012; 107(3):298-307.

15. Luo $Y$, Wang L, Chen $C$, Chen D, Huang M, Huang $Y$, et al. Simultaneous liver and colorectal resections are safe for synchronous colorectal liver metastases. J Gastrointest Surg 2010;14(12):1974-80.

16. Weber JC, Bachellier P, Oussoultzoglou E, Jaeck D. Simultaneous resection of colorectal primary tumour and synchronous liver metastases. Br J Surg 2003;90(8):956-62.

17. Adam R, De GA, Figueras J, Guthrie A, Kokudo N, Kunstlinger F, et al. The Oncosurgery Approach to Managing Liver Metastases from Colorectal Cancer: A Multidisciplinary International Consensus. Oncologist 2012 Sep 7.

18. Adam R, De GA, Figueras J, Kokudo N, Kunstlinger F, Loyer E, et al. Managing synchronous liver metastases from colorectal cancer: a multidisciplinary international consensus. Cancer Treat Rev 2015; 41(9):729-41.

19. Reddy SK, Pawlik TM, Zorzi D, Gleisner AL, Ribero D, Assumpcao L, et al. Simultaneous resections of colorectal cancer and synchronous liver metastases: a multi-institutional analysis. Ann Surg Oncol 2007; 14(12):3481-91.

20. Sabbagh C, Cosse C, Ravololoniaina T, Chauffert B, Joly JP, Mauvais $F$, et al. Oncological strategies for middle and low rectal cancer with synchronous liver metastases. Int J Surg 2015;23(Pt A):186-93.

21. Capussotti L, Ferrero A, Vigano L, Ribero D, Lo TR, Polastri R. Major liver resections synchronous with colorectal surgery. Ann Surg Oncol 2007;14(1):195-201.

22. Muangkaew P, Cho JY, Han HS, Yoon YS, Choi Y, Jang JY, et al. Outcomes of Simultaneous Major Liver Resection and Colorectal 
Surgery for Colorectal Liver Metastases. J Gastrointest Surg 2016; 20(3):554-63.

23. Jarnagin WR, Gonen M, Fong Y, Dematteo RP, Ben-Porat L, Little S, et al. Improvement in perioperative outcome after hepatic resection: analysis of 1,803 consecutive cases over the past decade. Ann Surg 2002;236(4):397-406.

24. Lambert LA, Colacchio TA, Barth RJ, Jr. Interval hepatic resection of colorectal metastases improves patient selection. Arch Surg 2000; 135(4):473-9.

25. Benoist S, Nordlinger B. The role of preoperative chemotherapy in patients with resectable colorectal liver metastases. Ann Surg Oncol 2009;16(9):2385-90.

26. de Haas RJ, Adam R, Wicherts DA, Azoulay D, Bismuth H, Vibert E, et al. Comparison of simultaneous or delayed liver surgery for limited synchronous colorectal metastases. Br J Surg 2010; 97(8):1279-89.

27. de Santibanes E, Lassalle FB, McCormack L, Pekolj J, Quintana GO, Vaccaro C, et al. Simultaneous colorectal and hepatic resections for colorectal cancer: postoperative and longterm outcomes. J Am Coll Surg 2002;195(2):196-202

28. Fukami $Y$, Kaneoka $Y$, Maeda A, Takayama $Y$, Onoe S, Isogai M. Simultaneous resection for colorectal cancer and synchronous liver metastases. Surg Today. 2016;46(2):176-82.

29. Mayo SC, Pulitano C, Marques H, Lamelas J, Wolfgang CL, de SW, et al. Surgical management of patients with synchronous colorectal liver metastasis: a multicenter international analysis. J Am Coll Surg 2013;216(4):707-16.

30. Reddy SK, Zorzi D, Lum YW, Barbas AS, Pawlik TM, Ribero D, et al. Timing of multimodality therapy for resectable synchronous colorectal liver metastases: a retrospective multi-institutional analysis. Ann Surg
Oncol 2009;16(7):1809-19.

31. LiverMetSurvey.com Semestrial statistics. 2017. Ref Type: Online Source

32. Reddy SK, Barbas AS, Clary BM. Synchronous colorectal liver metastases: is it time to reconsider traditional paradigms of management? Ann Surg Oncol 2009;16(9):2395-410.

33. Bonney GK, Coldham C, Adam R, Kaiser G, Barroso E, Capussotti $\mathrm{L}$, et al. Role of neoadjuvant chemotherapy in resectable synchronous colorectal liver metastasis; An international multi-center data analysis using LiverMetSurvey. J Surg Oncol 2015;111(6):716-24.

34. Ayez N, van der Stok EP, Grunhagen DJ, Rothbarth J, van ME, Eggermont AM, et al. The use of neo-adjuvant chemotherapy in patients with resectable colorectal liver metastases: Clinical risk score as possible discriminator. Eur J Surg Oncol 2015;41(7):859-67.

35. Tanaka K, Adam R, Shimada H, Azoulay D, Levi F, Bismuth H. Role of neoadjuvant chemotherapy in the treatment of multiple colorectal metastases to the liver. Br J Surg 2003;90(8):963-9.

36. Ayez N, van der Stok EP, de WH, Radema SA, van HR, Roumen RM, et al. Neo-adjuvant chemotherapy followed by surgery versus surgery alone in high-risk patients with resectable colorectal liver metastases: the CHARISMA randomized multicenter clinical trial. BMC Cancer 2015;15:180

37. Martin RC, Augenstein V, Reuter NP, Scoggins CR, McMasters KM. Simultaneous versus staged resection for synchronous colorectal cancer liver metastases. J Am Coll Surg 2009;208(5):842-50.

38. Abbott DE, Cantor SB, Hu CY, Aloia TA, You YN, Nguyen S, et al. Optimizing clinical and economic outcomes of surgical therapy for patients with colorectal cancer and synchronous liver metastases. J Am Coll Surg 2012;215(2):262-70. 